YUUrGU. Seriya: Sotsial'no-gumanitarnyye nauki, № 1. Retrieved from https://cyberleninka.ru/article/n/ekranizatsii-bratiev-strugatskih-i-evolyutsiyaotechestvennogo-kinematografa.

8. Strugatskiy, A., Strugatskiy, B. (1993). Strana bagrovykh tuch: Povest'. Rasskazy. Stat'i, interv'yu. [Country of crimson clouds: A Story. Stories. Articles, interviews.]. Moskow, Tekst.

9. Strugatskiy, A., Strugatskiy, B. (1992). Ulitka na sklone $i$ dr. [Snail on a slope, etc.]. Moskow, Tekst.

10. Frolov, A. V. (2012). Problema periodizatsii tvorchestva Arkadiya i Borisa Strugatskikh [The problem of periodization of the work of Arkady and

I. V. Bratus, PhD, Associate Prof.

Borys Grinchenko Kyiv University,

I. Shamo boulevard, 18/2, Kyiv, 02154, Ukraine
Boris Strugatsky]. Vestnik BGU, № 2(1). Retrieved from https://cyberleninka.ru/article/n/problema-periodizatsii-tvorchestva-arkadiyai-borisa-strugatskih.

11. Chubays, I. (2021). Rasskaz 5. Novoye nastupleniye vlasti, 19461953 [New offensive of power, 1946-1953]. Retrieved from echo.msk.ru/blog/i_chub/2823388-echo/

Надійшла до редколегії 23.04.21

\title{
COUNTERACTION TO THE SYSTEM AND ANTI-SYSTEM IN THE STRUGATSKY BROTHERS'STORY "SNAIL ON THE SLOPE"
}

Aspects of countering the system and anti-system are considered in the Strugatsky brothers 'novel "Snail on the slope". It is proved that science fiction writers managed to recreate quite complex aspects of the interaction of various systems within the framework of literary heritage. The broad palette of writers has absorbed an understanding of contradictions with underlying causes. In this article, some aspects of the interaction of the individual and the system, systems and anti-systems are demonstrated. Special attention is paid to the Soviet realities, which became the basis for the artistic picture of the fantastic world. This indicates the uniqueness of "Snail on the slope". One of the unique qualities is the influence on the story "Snail on the slope" by Franz Kafka (novels "The Process", "The Castle"). When analyzing the story, the focus of countering the system and the antisystem is transferred to the idea of the future. It is proved that the writers abandoned the continuous optimistic model of the future inherent in their earlier works. Strugatsky brothers have worked out in detail the mechanism of the inability to evolve into the future without radical changes in the essence of man. The literature of the second half of the twentieth century contains an extraordinary potential for understanding our current realities. Somewhere we are even in a more "winning" position - the authors and readers of that time had a more narrowed range of analysis, which was naturally inherent in "their time". At the same time, we are also partially vulnerable, especially in the historical and cultural context. Because the time of writing a work leaves an imprint on its content, the keys to its understanding are often in the social parallels of everyday life, which is fully understood by contemporaries, and "descendants" need to explain certain specific aspects of everyday life, psychological model or banal meaning of a particular word (they become anachronisms or acquire a different meaning). At the same time, it is worth paying attention to those questions that are transcendental in nature. Strugatsky brothers in "Snail on the Slope" experienced a corresponding experience - they tried to create a multi-faceted picture of the world with "their own" laws. At the same time, the task they set was not only to come up with, but also to "guess" the true concept, to bring the artistic fabric of the work closer to the "truth of life". Therefore, this work is fundamentally different from a significant part of their literary heritage, it is a kind of "experimental platform". They did not try to repeat this experience in their future work

Keywords: fiction, Strugatsky, system, anti-system, literature, Kafka, USSR.

И. В. Братусь, канд. филол. наук, доц.

Киевский университет имени Бориса Гринченко,

б-р И. Шамо, 18/2, г. Киев, 02154, Украина

\section{ПРОТИВОДЕЙСТВИЕ СИСТЕМЫ И АНТИСИСТЕМЫ В ПОВЕСТИ БРАТЬЕВ СТРУГАЦКИХ "УЛИТКА НА СКЛОНЕ"}

Рассмотрены аспекты противодействия системы и антисистемы в повести братьев Стругацких "Улитка на склоне". Доказано, что фантастам удалось воссоздать довольно сложные аспекты взаимодействия различных систем в рамках литературного наследия. Широкая палитра писателей впитала в себя понимание противоречий, имеющих глубинные причины. В статье продемонстрировано некоторые аспекты взаимодействия личности и системы, системы и антисистемы. Особое внимание уделено советским реалиям, ставшим основой для художественной картины фантастического мира. При этом указывается на уникальность "Улитки на склоне". Одним из уникальных качеств является влияние на повесть "Улитка на склоне" творчества Ф. Кафки (романы "Процесс", "Замок"). При анализе повести фокус противодействия системы и антисистемы переносится на представление о будущем. Доказано, что писатели отказались от присущей им в более ранних произведениях сплошной оптимистической модели будущего. Братья Стругацкие подробно проработали механизм невозможности эволюционировать в будущее без коренных изменений в сущности человека.

Ключевые слова: фантастика, Стругацкие, система, антисистема, литература, Ф. Кафка, СССР.

УдК 130.2

В. С. Гриценко, канд. філос. наук, доц. Київський національний університет імені Тараса Шевченка, вул. Володимирська, 60, м. Київ, 01033, Україна valentynagrytsenko@knu.ua

\section{СХІД ЯК КУЛЬТУРНИЙ ТРЕНД}

Присвячено одному з найскладніших явищ діалектики розвитку культури - індивідуальній духовній ідентифрікації шляхом вибору й освоєння іншокультурного духовного ресурсу, а саме - окремих складових традиційних культур Китаю і Японії. Усупереч його переважно фактологічному науковому розгляду в контексті питань культурних запозичень "духовну міграцію" на Схід проаналізовано як стійку тенденцію, що має своїм джерелом сутнісні інтенції людини, залишаючись не лише константною у багатовіковому минулому людства, а й непозбутньою в його подальшій культурній ході. У цьому контексті розглянуто історичні вияви підвищеного інтересу до надбань далекосхідного культурного ареалу, його трансформацію від простого захоплення екзотами до сповідування представлених ними філософсько-світоглядних орієнтирів. Досліджене у такий спосіб явище культурного тренду, продемонструвавии свою здатність виявляти та зберігати духовні рекреації, розкрито у своєму прямому зв'язку з діалектичними процесами культурного розвитку людства.

Ключові слова: далекосхідний культурний ареал, іншокультурний духовний ресурс, культурний тренд, духовна самоідентифікація, акцентні соціокультурні запити, духовна міграція, компенсаційні "трендові вузли".

Постановка проблеми. Схід здавна привертав до себе увагу. Не змінилось це і в наш прагматичний час, коли перемоги й успіхи вимірюють переважно матеріальним зиском, а не досягненнями духовного сенсу. Однак не можна не відзначати послідовність спрямувань, непересічну завзятість та всеперемагаючу наполегливість східних фрлагманів світового розвитку, не можна не замислюватись, що за цим стоїть. В одному випадку цей інтерес пов'язаний з бажанням повторити успішний досвід, в іншому, - мотивований передчуттям незви- 
чайних внутрішніх відкриттів, недоступних в умовах буденщини. Потреба в них супроводжувала людину завжди, лише змінюючи свої акценти й інтенсивність. Остання, як доводить історія, перебуває у прямій залежності від духовного дефіциту, отже, зрозуміло, наскільки це актуально для нашого часу. Попри це домінує перша тенденція, стимульована інтересами політики та бізнесу, що зазвичай націлені на швидкий і практичний результат. Друга ж, обираючи сенсожиттєві орієнтири, потребує наполегливої внутрішньої роботи і може мати дистанцію довжиною в життя, а отже, рекрутує із соціуму тих, хто, відчуваючи таку потребу, здатний свідомо стати на цей непростий і по-справжньому звитяжний шлях.

Глибоко особистий корінь цієї інтенції сформований у надрах суспільних відносин і $€$ реакцією на їхню сприятливість для духовного самоздійснення: пошук чи створення "духовних ніш", активізація зусиль у цьому напрямі, на жаль, свідчать нині не про настання загального "просвітлення", а про наявність духовного неблагополуччя. Урешті, така залежність існувала завжди, хоча й виявлялась по-різному, і Схід, визнана духовна рекреація, має в цьому розумінні свою давню історію. Його особливе місце в ряду культурно-географічних дихотомій, здавна надане йому європейцями, багаторазово підтверджено загальновизнаними фактами й легітимовано реаліями сьогоднішнього дня. Питання ж про те, чи стане прагматика інтересу до Сходу одним із маршрутів до людського духовного ядра, залишається відкритим, адже вирішує його не час, а енергія духовного запиту, сформована реальними обставинами життя. Зрештою, історія людства неодноразово спостерігала перетворення зневаги на зацікавлену увагу, нехтування - на наслідування, зверхності - на учнівство.

У цьому є своя закономірність, що належить до сутнісного рівня розуміння людини, з позицій якого рух до повноти її самореалізації здійснюється одночасно у двох площинах - індивідуальній і родовій, представленій цілокупністю різноманітних виявів роду "Людина". 3 огляду на це в зазначеному випадку зміна позиції на протилежну $є$ не актом спонтанного вибору, а кроком культурного самовизначення. У цьому смислі розмова про моду на якусь культурну модель $є$ нічим іншим, як з'ясуванням чинників, обставин і наслідків такого повороту, невипадкових і важливих для загального розвитку людства. Відмінності в їхній історичній атрибуції суті не змінюють, чи-то часи античності, хвилі європейської колонізації світу або духовна криза, яку переживаємо нині, - в усіх без винятку випадках маємо справу із процесами духовної самоідентифікації, які $€$ родовим способом збереження і відтворення людського коду.

3 цих позицій поділ світу на Захід і Схід є значною мірою умовним, адже географічні, політичні й культурно-цивілізаційні відмінності, ураховані у відповідних типологіях, звичайно ж, спостерігаються, однак не відкидають стрижневого руху, збагачуючи його різнобарв'ям людських виявів. Саме тому звернення до Сходу у такому випадку має на меті не його традиційне протиставлення Заходу, а з'ясування його ресурсності для збереження і розвитку роду "Людина". Апеляція ж у цьому сенсі до надбань далекосхідного культурного регіону, зокрема до Китаю і Японії, має свою вагому підставу їхню роль у процесах культурного самовизначення, те "духовне щеплення", завдяки якому Європа додала до своїх внутрішніх запасів розуміння інших шляхів досягнення впевненої рівноваги і самодостатності.

Створені в такий спосіб "духовні дріжджі" завжди напоготові: подолавши кордони й нового світу, вони, фактично, стали загальним духовно-рекреаційним ресурсом, здатним впливати на людинотворення через життєствердні світоглядні регулятиви та позитивні поведінкові стратегії. Філософрія культури, культурологія не може залишати це поза увагою, зважаючи на суттєві духовні втрати, пов'язані, зокрема, із сучасним обездуховленням усіх сторін людського буття. Дослідження сьогоднішньої моди на Схід стає, таким чином, необхідною частиною соціокультурних проєктів, спрямованих на збереження людини як значущої складової світобудови.

Аналіз досліджень і публікацій. Схід як об'єкт дослідження має по-справжньому неосяжний масив наукових розробок і не меншу кількість векторів їхнього спрямування. У запропонованому ракурсі бачення Сходу є інноваційним, що не відкидає, а, навпаки, передбачає необхідність вивчення напрацювань, що ввели його у простір культурологічної аналітики. Закріпившись там як постійно діючий евристичний пульсар, Схід акумулює всі свої дослідницькі площини, тримаючи їх у стані постійного взаємовпливу, що передбачає у розв'язанні теоретичних питань обов'язковість міждисциплінарного "допуску". У нашому дослідженні він реалізований у поєднанні таких складових, як власне культурологія, фрілософія, історія й орієнталістика, що засвідчено залученими до нього концепціями та науковими джерелами.

Для розуміння логіки взаємин Заходу і Сходу й коректного оперування фактами було задіяно відповідну історіографію, представлену ранніми, зокрема грекоримськими, античними джерелами (Арістотель, Пліній Старший), а також ретроспективним поглядом на їхні стосунки з позицій сучасних історичних знань (М. Кюнер, О. Петров, О. Фішман та ін.). Принципове значення для нашого аналізу виявили дослідження процесів формування та чинників трансформації їхніх уявлень відносно своїх візаві (Д. Дубровська, Л. Кроль, О. Філіппова, О. Цісельська). Серйозну дотичність до цього показали позиції сходо- і заходофільства, представлені, зокрема, Ф. Берньє, Л. Левайє, Вольтером, Ф. Кене, Ш.-Л. Монтеск'є, Г. В. Лейбніцем, Х. Вольфом, Г.В.Ф. Гегелем.

"Книга чудес світу" Марко Поло, ставши дороговказом для численних поколінь мандрівників і шукачів пригод і див, увела дослідження в царину орієнталістики, яка в описах мандрівок, дорожніх нотатках, свідченнях місіонерів і дипломатичних звітах знаходить культурознавчий зміст, важливий для з'ясування крос-культурних взаємодій Сходу і Заходу (Д. Дубровська, О. Фішман). Цей масив джерел, що інтенсивно розширювався із часів великих географрічних відкриттів, продовжує мати пізнавальне значення через багатство фактології, яка неспростовно підтверджує сталість інтересу до Сходу, здатного виражатися через формування відповідних трендів - акцентних соціокультурних запитів. У відслідковуванні актуальних тенденцій і домінант міжкультурної динаміки окрему експертно-діагностичну роль виконав якісний культуртрегерський контент сучасних туристичних сайтів.

Проблема вибору для самоідентифікації іншокультурної духовної моделі лежить у філософській площині, що спрямувало увагу до спроб з'ясувати причини і цілі "культурної міграції", однією з яких виявилась аналітика, розгорнута західноєвропейськими дослідниками дзенбуддизму (К. Юнг, Е. Фромм, А. Уотс, А. Швейцер й ін.). Констатуючи "духовну кризу західної людини", вони вбачали в ній шлях до реалізації їі початкової чистоти і шляхетності, до абсолютної гармонії зі світом. Ця позиція закріпила в європейській свідомості уявлення про духовну компенсаційність Сходу, чинне і нині, - так західний раціоналізм визнав перемогу східної "філософії серця", відкривши свій культурний простір сприйняттю її духовних меседжів, яскраво втілених в екзотичних для європейців явищах передусім морально-естетичного плану. 
У з'ясуванні процесів формування моди на предмети далекосхідного мистецтва продуктивним виявилося звернення до досліджень, присвячених впливу східної естетики на європейську художню культуру, появі та розповсюдженню стилю "шинуазрі" (Д. Джекобсон, М. Максимова, Н. Науменкова, М. Неглінська, Н. Ніколаєва, Е. Чистякова). Важливими для цілісності бачення цих процесів стали й подібні роботи їхніх візаві - представників китайської і японської культури (Ву Ю-Фанг, Х. Ватанабе, Т. Кензо, Ян Чжи й ін.). У процесі розгляду зазначеного аспекту проблеми був проаналізований значний масив джерел, пов'язаних із виявами сучасної моди на китайсько-японський Схід, зокрема, у fashion, ландшафтній архітектурі, дизайні (О. Голосова, М. Ішмуратов, Т. Кензо, О. Козлов, К. Кукліна, Н. Науменкова й ін.).

Метою статті $€$ аналіз моди на Схід як закономірного явища розвитку культури, пов'язаного із проблемами духовної самоідентифікації та пошуку людиною продуктивних духовно-рекреаційних ніш поза межами власної культурної автохтонності.

Виклад основного матеріалу дослідження. Вираз "діалог культур" давно оселився в науці як стійке словосполучення, перетворившись урешті на своєрідний штамп, що кочує від однієї її сфери до іншої, починаючи від етнографії й закінчуючи політологією. Насправді ж, окрім мовленнєвої яскравості, він має чіткий понятійний смисл і важливе концептуальне значення. Мультикультурність світу, укотре усвідомлена людством - тепер уже у проєкті глобалізації, здавалося б, мала оперувати поняттям полілогу. Так не сталося не з випадкових причин і, звичайно, не через складності багатосторонньої комунікації.

Причина в іншому - у проблемах культурної (читай - духовної) ідентифікації, акцентованих і водночас загострених складними глобалізаційними процесами. Ідея створення планетарного дому на основі загальнолюдських цінностей мала потужний гуманістичний потенціал, спрямовуючи на єднання й духовне взаємозбагачення всупереч регіоно- та етноцентризму. Та світ рушив іншим шляхом - шляхом стандартизації й уніфікації, що з необхідністю пробудило в культурах доцентрові сили, спрямовані на самозбереження, яке виразилось у потребі глибокого усвідомлення та повноцінного відтворення власного духовного ядра як унікального ідентифрікатора у культурному пазлі людства. Із цим пов'язано сучасне зростання етнічної самосвідомості, поява гіпертрофованих й подекуди агресивних форм її пред'явлення. У таких умовах діалог культур набуває форми духовних маніфестацій, потреба в яких зростає з ускладненням самостояння людини в сьогоднішніх обставинах буття.

В історії людства потреба в діалозі народжена, як відомо, прагматикою фрізичного виживання та процесами ойкуменічного утвердження. Мапа таких діалогконтактів постійно розширювалась у відповідь на нові й нові запити людини. Зрештою, на ній рельєфно пролягли шляхи, що попри географічну основу давно сприймаються як смислові антиномії: "Північ - Південь", "Захід - Схід". Остання - великою мірою завдяки європоцентризму, продукту культурної зухвалості європейців-колонізаторів. Успіх буржуазних революцій, досвід парламентаризму, п'янкий ентузіазм карколомних перетворень заклали фундамент зверхності щодо колонізованих народів, що поширилась за межі загарбаних земель у вигляді ідеї європейської еталонності передусім у розумінні прогресу та шляхів до нього.

Значною мірою посприяла цьому поява на політичній авансцені молодого класу буржуазії, сповненого креативних сил і пафосних амбіцій, що стало каталізатором змін у суспільній свідомості, запорукою завоювання демократичних прав і свобод у процесі революційних рухів, розгорнутих у Європі із середини XVII ст. На тлі успіхів ії модернізації перехід до широкої колоніальної експансії сприймався як перевага європейської цивілізаційної моделі й, таким чином, - як підстава для іiї світового розповсюдження та сприяння ії̈ беззаперечному наслідуванню. Історично сформована самовпевненість старого світу отримала новий імпульс від буржуазного максималізму: переконаний у своєму праві на перетворення світу за власним розумінням, прагнучи першості в усьому, він з ентузіазмом вкладався в колоніально-торговельні проєкти, нехтуючи культурноцивілізаційними відмінностями з висоти європейської амбітності, не готової поступатися своїми інтересами. Знову, як у часи перших великих географічних відкриттів, самовідчуття європейців повнилось впевненістю у своїй цивілізаційній всепереможності та непересічності. Від цієї точки чи, радше, знака оклику прокладали маршрути до далеких й незнаних земель, спрямовані пануючим меркантилізмом та жагою наживи.

Зустріч із Китаєм, а згодом із Японією, обіцяла неабиякі перспективи, підтверджені товарами, що потрапляли на європейський ринок. Свідчення мандрівників і місіонерів, звіти посольств, праці, нерідко написані 3 чужих слів, підготували уяву європейців до фантастичних картин, що зблякли при прямому контакті із цими ні на що не схожими країнами, які вражали на кожному кроці, переважаючи магнетизм уже знаних культур, зокрема дива Індостанського субконтиненту. Підвищена ділова активність неодноразово розбивалась об скелю споглядальної життєвої позиції, перш ніж за нею відкрилася принципово відмінна від звичної для європейця модель світосприйняття та самовизначення - філософсько-універсалістська. Цивілізаційна відмінність не приховала від європейського погляду стійкість поведінкових моделей, особливе ставлення до природи, оригінальність жанрів мистецтва й художніх практик, внутрішній потяг до естетизму, що народив, зокрема, феномен так званих китайських речей і чарівний світ кімоно 3 його витонченими аксесуарами тощо.

Зрештою, сталося неочікуване - характерні для обох народів стійкий ментальний моноцентризм, спротив акультурації як загрозі корінному духовному ядру викликали в європейців дражливе відчуття внутрішньої недостатності, власної духовної неповноти. Так перше відчуття нездоланності культурної іншості перетворилось на усвідомлення ії особливої ролі у власному духовному самоосягненні. Незабаром це зрозуміли й ті, кому не вдалося побачити далекосхідні таїни на власні очі: китайські і японські товари, наповнюючи європейські ринки, були агентами своїх культур, транслюючи їхній унікальний духовний досвід. Саме він в опосередкованій формі ставав предметом попиту, тим більшим, чим гостріше відчувалися духовні втрати від меркантилізації життя та панування індивідуалізму. Захоплення далекосхідними екзотами вважали не лише ознакою хорошого смаку, а й доказом неабиякої духовності.

Загострення інтересу до Сходу, у колі якого опинилися Китай і Японія, було пов'язано і з пошуком європейськими державами шляхів подальшого політичного розвитку, що знайшло свій вияв у протистоянні заходоі сходофрілів. Відстоюючи модель просвіченої монархії, прихильники Сходу спиралися на приклад китайського абсолютизму, попри недостатність свідчень про нього. Десятиліттями дискусія втягувала у своє річище нові й нові аргументи, залишаючи Піднебесну темою постійного обговорення. Під впливом авторитетів, таких як Во- 
льтер, сформувалась і побутувала думка про ії суттєві переваги порівняно з Європою. Навіть зі збільшенням знань, що спростовували підстави для такої позиції, інтерес до неї не згасав. Навпаки, з легітимацією індивідуалізму як моральної норми, з утвердженням буржуазності як способу суспільного буття ця цікавість виявила сталу тенденцію до зростання, постаючи компенсатором існуючих і можливих духовних втрат.

У цій ситуації стабільна духовна вертикаль, що віками живила китайський i, як виявилось згодом, японський народи, набула особливої притягальної сили передусім для тих, хто за нових умов не втратив енергії самовдосконалення та духовної відповідальності за збереження повноти своєї людської суті. Це звернення до самого себе не було виявом розумного егоїзму, що піднімався на щит як ознака моралі молодого буржуазного суспільства, оптимальна модель узгодження особистих і суспільних інтересів. На нашу думку, тут ми маємо справу 3 явищем іншого порядку - із виявом інтуїції всеєдності як родозберігального відчуття людини. Формуючись на рівні універсалій, вона переважає етнорегіональну модель людської ідентифікації, резонуючи в цій специфіці лише 3 ознаками загальнолюдського характеру.

Як зараз, так і тоді ця інтуїція навідувала далеко не всіх, потребуючи розвиненого духовного ґрунту; загалу ж лишалась юдоль індиферентності чи, у кращому випадку, - ентузіазм сприйняття інакшого як джерела нових переживань, сповнених хвилюючих духовних пригод, рідкісних у звичайному житті. Слід визнати, що саме він, залишивши "вівтар" небагатьом обраним, заклав засади новочасної моди на Схід. Вогонь, що буде в ньому жевріти, запалить у майбутньому не одне серце. А поки що, у часи пристосування до нового соціального порядку, сформувалась акцентна увага до зовнішнього боку незвичних й від того дуже привабливих речей. Вона мала здолати непростий шлях до розуміння їх антропоцентричного смислу і прихованих духовних кодів. Європейців відчутно наблизить до нього проблема відчуження, коли воно з ледь уловимих суспільних тенденцій перетвориться на факт особистого життя.

Починався ж цей шлях у далекі часи європейської античності. Рим, охоплений "шовковою лихоманкою", навряд щось достеменно знав про батьківщину міцної і водночас ніжної тканини, що прекрасно захищала від спеки, дбаючи водночас і про здоров'я тіла. Однак ця опосередкована форма знайомства з таємничою країною мала, крім практичної користі, ще один важливий наслідок: статусна розкіш китайського шовку збіглася 3 пафосною ідеєю римської богообраності, зав'язавши перший трендовий вузол у стосунках Європи з Китаєм. Як не намагався римський сенат заборонити економічно виснажливе носіння шовку, воно залишалося модним, ставши знаком елітності, належності до верхівки суспільства. Купуючи тканину за золото, римлянин отримував значно більше, ніж можливість мати шовкову тогу: унікальність шовку він переживав як ознаку власної непересічності і був готовий за це платити ще і ще. Парадоксальним чином спрацьовувало й те, що цей пріоритет на відміну від інших не було завойовано. Меседж чужої культури, шовк оминув прямолінійну войовничість римлян, звернувшись до їхньої чуттєвості, загостреної постійним почуттям небезпеки. Це був власний вибір компенсаційного характеру: утомлена постійним підтриманням войовничості душа потребувала внутрішнього затишку, який відчула за першого ж дотику шовку до тіла. Отже, моду на нього стимулювали два чинники: з одного боку, необхідність відповідати високому соціальному статусу, з іншого - інтуїція духовного самозбереження.
Досвід цього культурного контакту зберігся в пам'яті Європи, залишивши відчуття невичерпаності стосунків зі Сходом поряд із бажанням їхнього продовження. Посилання на Китай у давньогрецьких і давньоримських джерелах були надто спорадичними, щоб пожвавити цей процес. Він відбувався хвилеподібно, посилюючись чи завмираючи. Сучасні дослідники євразійських кроскультурних взаємодій стверджують, що "розповідь про те, як Європа побачила "світ зі Сходу", починається 3 епохи Великих географрічних відкриттів..." [4, с. 194]. Із цим важко не погодитись, якщо розуміти, що, врешті, ідеться про початок постійних контактів, які мали не однобічний, а двосторонній вплив. Отже, і твердження, що "у XV-XVI ст. відбулося поширення європейського впливу" [4, с. 194], потребує такого ж корегування. На всіх без винятку етапах активізації контактів Європи 3 Китаєм, починаючи із проникнення в Піднебесну у XIII ст. францисканців і Марко Поло, обидві сторони, зважаючи на їхні принципові світоглядно-ментальні відмінності, переживали культурний стрес і досить складний процес культурної реабілітації. Однак, прискіпливо вдивляючись одна в одну, вони краще пізнавали себе, збагачуючи самоусвідомлення додатковими барвами і новими критеріями. Упродовж століть це залишається незмінним. Отже, Європа і Захід загалом потребують свого дослідника в ролі культурних трендів: шалена популярність у далекосхідних країнах зміни обличчя на європейський лад навряд чи є єдиним доказом їхнього існування.

Часом справжньої синоманії в Європі, що підняв хвилю моди на все китайське, стала вже згадувана доба Просвітництва, надзвичайно потужна у культуротворчій роботі, яка охопила всі сфери діяльності суспільства. Нічого не взявши на віру, вона рушила шляхом раціонального осягнення світу, беручи за основу реальні факти. Отож, і фрлер, що оповивав Піднебесну з отримання перших, вражаючих, відомостей про неї, мусив зникнути, поступившись реалістичному погляду. Так сформувалася суперечність між практичним запитом, корисним для продуктивного розвитку подальших стосунків з Китаєм, і позицією тих, хто вже потребував збереження для себе його внутрішньої іпостасі.

Парадоксальним чином ця суперечливість не завадила закладанню нових цеглин у фундамент орієнталістики, однак назавжди залишила в ній дві поєднані інтенції - прагнення об'єктивності й зачарованість Сходом, чий баланс і взаємопроникнення не сумісні з європоцентризмом. Варто зазначити, що в часи соціальнополітичного перетворення Європи сама зачарованість мала специфічний - дуальний - характер: відцентрове і доцентрове спрямування, де перше керувалося духовним пошуком, спрямованим у бік фрілософськосвітоглядних універсалій, друге - задоволенням від гостроти переживання, що виникало при контакті з незвичайним, екзотичним, збуджуючи нетривіальні почуття, а нерідко й креативні інтенції. Зрозуміло, що в обох випадках це інше не ставало й не могло стати своїм, однак виконувало надзвичайно важливу функцію розширювало духовне бачення шляхом подолання етнокультурної ангажованості. Цілком закономірно це народжувало бажання постійного контакту чи обов'язкової наступної зустрічі. Одним з варіантів його задоволення ставала мода, яка попри спільну основу не була однорідною, маючи різні суспільні вияви: політичні, філософські, художні, побутові тощо.

Опублікування 1687 р. в Парижі "Confucius Sinarum Philosophus", важливої частини конфуціанських текстів, утвердило думку щодо далекосхідного лідерства Китаю, що залишилось незмінним й після знайомства Єв- 
ропи з Японією. Однак далекосхідний ареал сприймався європейцями як ціле з умовними лініями культурної диференціації. Неподільним було і прагнення оволодіти всіма його символічними смислами, прихованими, зокрема, й у світі його речей. На європейському ринку їх було вже достатньо, щоб дивувати, підігрівати цікавість, викликати захоплення, загострюючи попит. Поява моди на них наповнила Європу далекосхідними товарами, спростувавши при цьому одну із закономірностей існування тренду - припинення чинності з настанням загальної доступності. За стабільного зростання пропозиції потреба в них не згасала, а збільшувалася пропорційно розширенню знань про східні ідеї і духовні практики, залишаючись перманентною попри хвилеподібність періодів загострення такого інтересу.

Так виявляє себе незгасний людський запит на самоусвідомлення та саморозвиток. Схід і зараз уміє тримати його в напрузі, як і тоді, коли європейці вперше зачарувались переливами ніжного шовку, витонченістю фарфорового посуду, дивовижною красою ваз, орнаментованими бронзовими дзеркалами, оригінальними прикрасами, унікальним китайським лаком, різноманітними шкатулками, яскравими різноколірними парасольками тощо. Раціонально налаштованому розуму вони несли чуттєві спокуси й по-новому хвилююче задоволення, допомагаючи збереженню духовного балансу. Потрапляючи в коло людської буденності, ці речі ставали акцентом, що задавав високий рівень самовідчуття, збагачував внутрішній світ знаками інших життєвих можливостей.

Їхня палітра розширилася завдяки так званому японізму (Ф. Бюрті) - впливу Японії (із ІІ пол. XIX ст. до Першої світової війни) на мистецтво й інші сфери життя. Японські гравюри укійо-е, сувої какемоно, фарфор, кімоно, лакові вироби, представлені 1867 р. на Всесвітній виставці у Парижі й повністю розпродані, стали переломним моментом у знайомстві з японською культурою, її духовними засадами. Вона ще більше загострила розуміння речей як носіїв символічних смислів, "експортувала" душевний зв'язок людини і речі, навчила облаштовувати помешкання як територію панування універсалій. Зокрема, мода на японські ширми, задовольняючи естетичні потреби, впливала на вміння сприймати простір як цілісність, підвладну змінам, що відповідає загальним законам буття.

Поняття японізму, як й аналогічно вжите поняття китайщини, доводять неспростовність далекосхідного культурного внеску, відчутного і нині. Однак як "китайщина" було перекладено і французьке слово "шинуазрі", створене для позначення стилізації під майстрів Китаю й інших країн Східної Азії, імітації їхніх традицій у більшості видів мистецтва й, варто додати, - у способі облаштування життя. Зрозуміло, що в такому тлумаченні китайщина охоплює і японські явища. I все ж за терміном і послідовністю впливу домінантом тут залишається Китай. Що ж до власне шинуазрі, то його поява у XVII ст. на гребені схожого за декоративністю і витонченістю рококо і швидке закріплення в європейських, а згодом і світових трендах виявили відсутність культурної неперехідності, пов'язаної із природою людини. Це забезпечило стилю темпоральну необмеженість у трансляції духовних смислів далекосхідних культур. I нині він залишається у тренді в дизайні одягу й інтер'єру, в архітектурі та ландшафтному мистецтві. Його життєздатність обумовлена прагненням людини до повноти своєї самореалізації.

Мода на Схід, живлячись сутнісними людськими інтенціями, і зараз не керується лише любов'ю до екзотики. Навіть у fashion, де це було б доречно, така тенден- ція не домінує. Своєю творчістю це довів Кензо Такада, один з видатних майстрів світової моди. Формуючи свій стиль як симбіоз східної і західної культур, він спирався на традиційне японське світобачення, засноване на гармонізації стосунків людини зі світом. Oversize (вільний крій) Кензо став провідником його філософії, вираженої у творчому кредо: "Тілу потрібен простір. Як у фізичному, так і в духовному смислі". Одяг такого крою обирають ті, хто прагне справжньої особистої свободи, яка, за переконаннями Кензо, полягає у визнанні абсолюту природи і простих радощів життя.

Показовою у цьому розумінні $€$ й сучасна мода на китайські та японські сади, яка прагне наслідувати їхні традиційні форми. Свідомий вибір цих сповнених символізму ландшафтних моделей, їхнє відтворення та повсякчасне декодування стають справою особливого світоглядного налаштування, зміною особистих духовних регулятивів на принципи, що здатні змінювати саму модель буття.

Висновок. У культурології мода і процеси фрормування трендів належать до питань сутнісного ряду, адже виявляють мотивоване саморозвитком людини її постійне прагнення до змін. За історичними свідченнями, на орбіту моди як способу культурної ідентифікації потрапляють не лише речові та процесуальні феномени, а й культурно-світоглядні комплекси зі своєю моделлю світовідчуття та поведінкових регулятивів. Акцентний інтерес до них виникає з потреб самоідентифікації, проблематизованої обставинами особистого чи суспільного життя. Мотивом такого вибору стає пошук духовного оптимуму, сприятливого для самореалізації та внутрішньої свободи самовияву. Його відсутність формує компенсаційні "трендові вузли", чия поява $є$ передбачуваною, як і ресурс, потрібний для задоволення зазначеного культурного запиту. Він перебуває в розпорядженні культур, сформованих на основі фрілософськосвітоглядних універсалій, що розглядають людину як значущу одиницю Всесвіту. Частина з них пішла, однак культурна пам'ять людства зберігає згадку про їхній спадок, залишений для інтелектуалів. Цілісну ж дієвість ресурсу мають існуючі традиційні культури, що впродовж тисячоліть плекали своє духовне ядро, ставши меккою для духовно спраглих. Домінують у цьому Індія, Китай і Японія, що здавна уособлюють магнетичний Схід. Останні, у свій час відкрившись світу, не перестають вабити людство можливістю духовного зміцнення й оздоровлення у просторі вселенських координат, де здібності, мотиви і дії людини втрачають випадковий характер, набуваючи значення складових світобудови. Це кардинально змінює сенсожиттєві смисли, надаючи їм ознак вічності та нескінченності. Керованими стають важелі духовної самоідентифікації, втрачені через загальну прагматизацію суспільного буття. Активна багатовікова духовна директива, посилена сучасними цивілізаційними успіхами народів далекосхідного регіону, виправдовує акцентну зацікавленість у цій духовній ніші, що є суттєвою підставою сучасної моди на Схід. Можна бути впевненим, що із причин сутнісного порядку вона, маючи свої непоодинокі аналоги в минулому, може розраховувати й на перспективи в майбутньому.

\section{СПИСОК ВИКОРИСТАНИХ ДЖЕРЕЛ}

1. Алексеев М. П. Пушкин и Китай / М. Алексеев // Пушкин и Сибирь. - М.; Иркутск: Востсибоблгиз, 1937. - С. 108-145.

2. Ватанабэ Хиротака. Очарование японизма в Европе. [Електронний ресурс] / Х. Ватанабэ. - Режим доступу: https://www.nippon.com/ru/ column/g00284

3. Джекобсон Д. Китайский стиль / Д. Джекобсон. - М.: Искусство XXI век, 2004. - 239 с.

4. Дубровская Д. В. Иезуиты и эпоха Просвещения в Европе: новое видение Китая от Маттео Риччи до Адама Смита / Д. Дубровская // Ориенталистика. - 2018. - № 1 (2). - С. 194-208. 
5. Поднебесная империя в европейских изданиях XVII-XVIII вв. [Електронний ресурс]. - Режим доступу: http://press-libfl.tilda.ws/ podnebesnaya-imperiya-v-evropeiskih-izdaniyah-xvii-xviii-vv

6. Филиппова Е. С. Представление европейцев о Китае (к концу Средних веков - началу Нового времени) [Електронний ресурс] Е. Филиппова. - Режим доступу: https://portalus.ru/modules/history/ rus readme.php?subaction=showfull\&id=1175107128\&archive $=1447001994$ \&start_from $=\& u c a t=\&$

7. Фишман О. Л. Китай в Европе - миф и реальность (XIII-XVIII вв.) 1 О. Фишман. - СПб.: Петербург. Востоковедение, 2003. - 546 с.

8. Фрумкина Р. Зигфрид Бинг и рождение L'Art nouveau [Електронний ресурс] / Р. Фрумкина. - Режим доступу: https://trv-science.ru/ 2015/06/siegfried-bing-i-rozhdenie-lart-nouveau/

9. Шинкова А. И. История, анализ и атрибуция японской фарфоровой продукции Арита. Часть II. [Електронний ресурс]. / А. Шинкова. Режим доступу: https://teahouse-nsk.livejournal.com/326204.html

10. Japonism in Fashion. The Kyoto Costume Institute. [Електронний ресурс]. - Режим доступу: https://artsandculture.google.com/entity/ японизм/m05xkth?hl=ru

\section{REFERENCES}

1. Alekseev, M. P. (1937). Pushkin i Kitay [Pushkin and China]. In Pushkin i Sibir'. Moskow, Irkutsk, Vostsiboblgiz.

2. Vatanabe, Hirotaka. Ocharovanie eaponizma v Evrope [The charm of Japaneseism in Europe]. Retrieved from https://www.nippon.com/ru/ column/g00284

3. Dzhekobson, D. (2004). Kitayskiy stil [Chinese style]. Moskow, Iskusstvo XXI vek

4. Dubrovskaya, D. V. (2018). lezuity i epoha Prosvescheniya v Evrope: novoe videnie Kitaya ot Matteo Richchi do Adama Smita [Jesuits and the
European Enlightenment: A New Vision of China from Matteo Ricci to Adam Smith]. Orientalistika. № 1 (2), 194-208.

5. Podnebesnaya imperiya $v$ evropeyskih izdaniyah XVII-XVIII vv. [Celestial Empire in European editions of the XVII - XVIII centuries]. Retrieved from http://press-libfl.tilda.ws/podnebesnaya-imperiya-v-evropeiskihizdaniyah-xvii-xviii-vv

6. Filippova, E. S. Predstavlenie evropeytsev o Kitae k kontsu Srednih vekov - nachalu Novogo vremeni [Europeans' view of China (by the end of the Middle Ages - the beginning of the New Age)]. Retrieved from: https://portalus.ru/modules/history/rus readme.php?subaction=showfull\&id= 1175107128\&archive $=1447001994 \&$ start_from $=$ \&ucat $=$ \&

7. Fishman, O. L. (2003). Kitay v Evrope - mif I realnost (XIII-XVIII vv.) [China in Europe - Myth and Reality (XIII-XVIII centuries)]. SPb.: Peterburg. Vostokovedenie.

8. Frumkina, R. Zigfrid Bing i rozhdenie L'Art nouveau [Siegfried Bing and birth]. Retrieved from https://trv-science.ru/2015/06/siegfried-bing-irozhdenie-lart-nouveau/

9. Shinkova, A. I. Istoriya, analiz I atributsiya yaponskoy farforovoy produktsii Arita. Chast II [History, Analysis and Attribution of Japanese Arita Porcelain Products. Part II.]. Retrieved from https://teahousensk.livejournal.com/326204.html

10. Japonism in Fashion. The Kyoto Costume Institute. Retrieved from https://artsandculture.google.com/entity/японизм/m05xkth?hl=ru

Надійшла до редколегії 24.04.21

V. S. Gritsenko, PhD, Associate Prof.

Taras Shevchenko National University of Kyiv

60, Volodymyrska Street, Kyiv, 01033, Ukraine

\section{EAST AS A CULTURAL TREND}

The article is devoted to one of the most complex phenomena of the dialectic of cultural development - individual spiritual identification through the selection and development of individual components of a foreign cultural spiritual resource, in this case - the traditional cultures of China and Japan.

Contrary to its predominantly factual scientific consideration in the context of issues of cultural borrowing, "spiritual migration" to the East is analyzed as a stable trend, which has its source in the essential intentions of man, remaining not only constant in the centuries-old past of mankind, but also inescapable in its further cultural movement. In this context, the author considers the historical manifestations of heightened interest in the treasures of the Far Eastern cultural area, its transformation from a simple admiration for exotics to confessing the philosophical and worldview guidelines presented by them. The phenomenon of the cultural trend studied in this way, having demonstrated its ability to identify and preserve spiritual recreation, is revealed in its direct connection with the dialectical processes of the cultural development of mankind.

In culturology, fashion and the processes of trend formation belong to the issues of the essential series, because they reveal a person's constant desire for change motivated by self-development. According to historical evidence, the orbit of fashion as a way of cultural identification includes not only material and procedural phenomena, but also cultural and ideological complexes with their own model of worldview and behavioral regulations. The emphasis on them arises from the needs of personal self-identification, problematized by the circumstances of personal or public life. The motive for such a choice is the search for a spiritual optimum conducive to self-realization and inner freedom of self-expression. Its absence forms compensatory "trend nodes", the appearance of which is thus predictable, as well as the resource needed to meet this cultural demand. It is at the disposal of cultures formed on the basis of philosophical and worldview universals that consider man as a significant unit of the universe. Some of them are gone, but the cultural memory of mankind preserves the memory of their legacy left to intellectuals. The existing traditional cultures, which for thousands of years nurtured their spiritual core, becoming a Mecca for the spiritually thirsty, have the integral effectiveness of the resource.

Key words: Far Eastern cultural area, foreign cultural spiritual resource, cultural trend, spiritual self-identification, accent socio-cultural requests, spiritual migration, compensatory "trend nodes".

В. С. Гриценко, канд. филос. наук, доц.

Киевский национальный университет имени Тараса Шевченко,

ул. Владимирская, 60, г. Киев, 01033, Украина

\section{ВОСТОК КАК КУЛЬТУРНЫЙ ТРЕНД}

Посвящено одному из наиболее сложных явлений диалектики развития культуры - индивидуальной духовной идентификации посредством выбора и освоения отдельных составляющих инокультурного духовного ресурса, а именно - традиционных культур Китая и Японии.

Вопреки его преимущественно фактологическому научному рассмотрению в контексте вопросов культурных заимствований "духовную миграцию" на Восток проанализировано как устойчивую тенденцию, которая имеет своим источником сущностные интенции человека, оставаясь не только константной во многовековом прошлом человечества, но и неизбывной в его дальнейшем культурном движении. В этом контексте рассмотрены исторические проявления повышенного интереса к достоянию дальневосточного культурного ареала, его трансформация от простого восхищения экзотами до исповедания представленных ими философскомировоззренческих ориентиров. Исследованное таким способом явление культурного тренда, продемонстрировав свою способность выявлять и сохранять духовные рекреации, раскрывается в своей прямой связи с диалектическими процессами культурного развития человечества.

Ключевые слова: дальневосточный культурный ареал, инокультурный духовный ресурс, культурный тренд, духовная самоидентификация, акцентные социокультурные запросы, духовная миграция, компенсационные "трендовые узлы". 